\title{
Comments to Role of upper airway ultrasound in airway management
}

\author{
Wan-Ching Lien
}

See related research by Osman and Sum, https://jintensivecare.biomedcentral.com/articles/10.1186/s40560-016-0174-z.

With great interest, I read the article by Osman et al., entitled "Role of upper airway ultrasound (US) in airway management" [1]. The authors reviewed thoroughly for the various US applications for the upper airway, including prediction of endotracheal tube (ETT) size, difficult laryngoscopy, airway device placement and depth, percutaneous cricothyroidotomy, prediction of post-extubation stridor, and evaluation of the epiglottis.

Auscultation, waveform capnography, and chest X-ray are traditional methods for airway confirmation at critical or emergency situations. Although capnography is considered as the most reliable method, it may be biased by low cardiac output, low pulmonary flow, or epinephrine use in cardiac arrest patients [2]. US can be an alternative diagnostic tool for these conditions.

The standard image of tracheal US is a hyperechoic air-mucosa $(\mathrm{A}-\mathrm{M})$ interface with a reverberation artifact posteriorly (comet-tail artifact), surrounded by the thyroid glands. The esophagus is located at the posterior area of the left lobe of the thyroid gland [1]. Tracheal intubation is identified if only one A-M interface is present with one comet-tail artifact. If the second $\mathrm{A}-\mathrm{M}$ interface appears, which we call a "double-tract sign", esophageal intubation is diagnosed $[3,4]$. However, in the session of the ETT confirmation, the authors suggested that the "double-tract" or "double-lumen" sign was present when ETT position was in the trachea. There may be some misunderstandings.

\section{Abbreviations}

A-M: Air-mucosa interface; ETT: Endotracheal tube; US: Ultrasound

\section{Acknowledgements}

None.

\section{Funding}

None.

\section{Correspondence: wanchinglien@ntu.edu.tw}

Department of Emergency Medicine, College of Medicine, National Taiwan University and National Taiwan University Hospital, Hsin-Chu Branch, No.25, Lane 442, Sec.1, Jingguo Rd, Hsinchu City 300, Taiwan

\section{Availability of data and materials}

Not applicable.

\section{Competing interests}

The author declares that he/she has no competing interests.

\section{Consent for publication}

Not applicable.

Ethics approval and consent to participate

None.

\section{Author details}

Received: 26 November 2016 Accepted: 27 December 2016 Published online: 13 January 2017

\section{References}

1. Osman A, Sum KM. Role of upper airway ultrasound in airway management. J Intensive Care. 2016:4:52.

2. Takeda T, Tanigawa K, Tanaka H, Hayashi Y, Goto E, Tanaka K. The assessment of three methods to verify tracheal tube placement in the emergency setting. Resuscitation. 2003;56:153-7.

3. Chou HC, Tseng WP, Wang CH, Ma MH, Wang HP, Huang PC, et al. Tracheal rapid ultrasound exam (T.R.U.E.) for confirming endotracheal tube placement during emergency intubation. Resuscitation. 2011;82:1279-84.

4. Chou HC, Chong KM, Sim SS, Ma MH, Liu SH, Chen NC, et al. Real-time tracheal ultrasonography for confirmation of endotracheal tube placement during cardiopulmonary resuscitation. Resuscitation. 2013;84:1708-12.

\footnotetext{
Submit your next manuscript to BioMed Central and we will help you at every step:

- We accept pre-submission inquiries

- Our selector tool helps you to find the most relevant journal

- We provide round the clock customer support

- Convenient online submission

- Thorough peer review

- Inclusion in PubMed and all major indexing services

- Maximum visibility for your research

Submit your manuscript at www.biomedcentral.com/submit

Biomed Central
} 